Nives Ličen, Dušana Findeisen, Jasna Fakin Bajec

\title{
COMMUNITIES OF PRACTICE AS A METHODOLOGY FOR GRASSROOTS INNOVATION IN SUSTAINABLE ADULT EDUCATION
}

\begin{abstract}
In this article, we present findings on the characteristics of community of practice appearing in sustainable education in reference to preserving natural and cultural heritage. Our research originated in the poststructuralist theory of practice and in concepts of social learning. Freire's learning theory was the basis for establishing the thesis that critical awareness is necessary for sustainable innovation. The empirical section of our research is based on an ethnographical collection of data in three different environments. We analysed cases of connected learning and activities, based both in local community and participants' needs. All three cases join learning with innovative practices that develop social and environmental well-being. Our results reveal that innovative practices develop in connection with transformative learning: the dialogical linking of scientific and local behaviour and the identity of participants.
\end{abstract}

Keywords: transformative learning, community of practice, practice theory, sustainable development

\section{SKUPNOSTI PRAKSE KOT METODOLOGIJA ZA RAZVIJANJE INOVACIJ V IZOBRAŽEVANJU ODRASLIH ZA TRAJNOSTNI RAZVOJ - POVZETEK}

Članek prinaša ugotovitve o značilnostih skupnosti prakse pri izobraževanju za trajnostni razvoj v povezavi z ohranjanjem naravne in kulturne dediščine. Raziskava se je opirala na poststrukturalistično teorijo prakse in koncepte socialnega učenja. Izhajajoč iz Freirove teorije učenja, je bila postavljena teza, da je za inovacije v trajnostnem razvoju potrebno kritično ozaveščanje. Empirični del raziskave sloni na etnografskem zbiranju podatkov v treh okoljih. Analizirani so primeri povezovanja učenja in delovanja, ki izhajajo iz, lokalne skupnosti in potreb udeležencev. Vvseh treh primerih se učenje povezuje z inovativnimi praksami, ki razvijajo družbeno in okoljsko blagostanje. Rezultati kažejo, da se inovativne prakse

Ph.D. Nives Ličen, Associate Prof., Faculty of Arts, University in Ljubljana, Nives.Licen@ff.uni-lj.si Ph.D. Dušana Findeisen, Slovenian Third Age University Ljubljana, Institute of Research and Development in Education, Dusana.Findeisen@guest.arnes.si

Ph.D. Jasna Fakin Bajec, Research Centre at the Slovenian Academy of Sciences and Arts Ljubljana, jasna.fakin@zrc-sazu.si 
razvijajo v povezavi s transformativnim učenjem, dialoškim povezovanjem znanstvenega in lokalnega vedenja ter identitete vključenih.

Ključne besede: transformativno učenje, skupnosti prakse, teorija prakse, trajnostni razvoj

\section{INTRODUCTION}

Environmental pollution problems began with industrialisation and rapid development has only contributed to an increase in these problems during the last 50 years. Consequently, new concepts such as sustainable development have been encouraged. The research we present in this article links sustainable development with adult learning. Our research began with the Green Education Project (2013-2015) and originated in a) studying learning in the local environment (Grasseni, 2007; Manners, Wake and Carlise, 2009; Wenger, 2010; 2015), b) theories on lifelong and transformative learning (Cranton and Taylor, 2012; Orlović Lovren, 2012; Vidmar, 2014; Casey and Asamoah, 2016; Moyer, Sinclair and Quinn, 2016), and c) the concept of sustainable development presented in Slovenia by Plut (2006; 2014), Bogataj (2013), and Barbič (2005), and in various documents, such as Plan B for Slovenia 2.0 (2010). All three points present the need for education to enable people to build competencies for responding to new "wars for water, seeds and soil" and the related social power and social impact, as emphasised by ecofeminist interdisciplinary researcher Shiva $(2014 ; 2005)$. Evidence for the significance of education in mutual cooperation in sustainable development is found in international documents such as Rethinking Education: Toward a Global Common Good? (Unesco, 2015) and Transforming Our World: The 2030 Agenda for Sustainable Development (UN, 2015). Our research is ethnographical and based in our local environment, as we are interested in local innovative practices. Another starting point for our research was Grasseni's (2007) research of the community of practice in the local environment.

In our article, we will first describe theoretical bases, then analyse the work by the Sivka study circle, by a group of gardening volunteers at the Slovenian Third Age University, and by the Planina pri Ajdovščini Society of Housewives and Drama Group. The latter has been connecting village girls and wives with drama group actors since 2004. Through various interpretations (drama play, exhibitions, books, documentaries), it promotes village social life and presents ancestral traditions, as well as methods of creating innovative products based on traditional knowledge (e.g. growing old seeds) to the young.

\section{THEORETICAL BACKGROUND}

Sustainable adult education includes numerous goals, strategies, methods, and a variety of contents. It has various target groups, and is an amalgam of epistemological assumptions and theoretical bases. Environmental adult education (EAE) encourages people to actively participate in a community. Therefore, new educational methodologies often 
develop in connection with community-based adult education. During the last two decades, the EAE has seen intensive development, together with growing awareness of the dimensions and complexity of the environmental crisis, while its beginnings goes back to the 1970s ${ }^{1}$ (Clover, Jayme, Hall and Follen, 2013; Orlović Lovren, 2012; Monroe, Andrews and Biedenweg, 2007). In various environments, the EAE differs; it depends on the developmental status of the community, as well as its past experiences, knowledge, and aspirations, and often also depends on the current needs and the social and political situation. Sometimes the basic theme is environmental racism and sexism, which is outlined by ecofeminist authors (cf. Shiva, 2005), war and social instability, the submission of life to marketing and corporatisation ${ }^{2}$ (e.g. Clover, 2003, p. 5), while other themes focus more on preserving biodiversity and protecting ecosystems. Environmental education is interdisciplinary and connected to the preservation and sustainable use of natural and cultural heritage in conceptual and practical approaches. For example, The Smogbusters movement emerged within the National Heritage Trust in Australia, managed by the network of state conservation councils (Manners, Wake and Carlise, 2009). Our study was (is) also linked to the preservation of natural and cultural heritage. ${ }^{3}$

Researchers, politicians, and educators have recognised that the development of different social practices is necessary, since the fundamental system (which is unsustainable) fails to provide solutions for the emerging problems and also fails to support new lifestyles. Moreover, new problems emerge, combinations of environmental and social deficiencies, which are evident for example in ecological racisms, in which disadvantaged citizens are denied drinking water, etc. Lefay (2006 in Chen and Martin, 2015, p. 88) and O'Sullivan and Taylor (2004) argue that a change in awareness or a "quantum leap in consciousness" is needed if we want to stop the destruction of the natural environment, since environmental problems are rooted in the methods of decision-making and human actions.

Various educational strategies for EAE have been developed, however, the key limiting factor seems to be the efficiency of methods and strategies to change beliefs (in the frame of reference), habits, and daily behaviour (Chen and Martin, 2015), so it is necessary to follow the principles of transformative learning which are valid for various environments. EAE is taking place at universities, in social movements, in non-government organisations, in communities, and everywhere they search for more efficient learning methods

1 In 1972, the UN Conference on environment was held in Stockholm. In the 1970s, A. Naes (19122009), Norwegian philosopher and ecologist, introduced the term deep ecology and initiated the Deep Ecology Movement, suggesting the establishment of a new relationship between man and environment.

2 Corporatisation means that big international corporations take over small local businesses. They follow the principles of speculative capital, while local culture tends to disappear.

3 The concept of heritage includes not only protecting, restoring, exhibiting the selected artefacts, but also their use, modification, and adaptation to various modern needs. In short, heritage is still connected to history-, art history-, ethnology-, folklore-, etc. related goods (such as knowledge, skills, memories, experiences, etc.) of ancestors. It not only refers to the past, but also derives thereof the power to develop the present and to plan the future. New heritage roles are also connected to sustainable development policy (cf. Fakin Bajec, 2014, 2016a; 2016b; Harrison, 2008). 
which would have transformative effects on mental patterns and practices. The engaged method of theatre performance is often used (popular theatre, theatre of the oppressed). Moreover, action learning, collaborative learning, and outdoor experiential learning are used, since not only the transmission of information, but also the transformation of practices is important. We are examining the learning-action nexus (cf. Moyer, Sinclair \& Quinn, 2016), so consequently, our research derives from the theory of transformative learning, based in individual transformations, critical thinking, and social transformations (Cranton and Taylor, 2012), and in the community of practice model, developed by Lave and Wenger (Wenger, 2010).

The aforementioned notions demonstrate the need for innovative strategies and educational programmes. The latter are still based on the assumption that the more well-informed people are, the more their actions will change. Decision-makers derive their logic from the linear model, where the information added leads to a changed attitude, and that leads to different behaviour. Research (Chen and Martin, 2015, p. 87) reveals that this model, one that usually places emphasis on cognitive learning, is not the most efficient in developing new types of environmental behaviour. Human behaviour is influenced by social norms, emotions, attributed meanings, and problem awareness. Awareness and knowledge of environmental problems are important. Knowledge is in positive connection with environmental behaviour, however, its impact on behaviour is not the most significant. For example, advising for efficient energy use is most successful when combined with financial stimulations and experiential learning, and presented in dialogue with users. A higher impact can be achieved by assessing social norms, personal moral norms, the formation of meanings in reference to a person's active role, and responsibility. Cognitive education models of transmission are therefore not enough. We also need social models or contextual models of transformative learning, rooted in a person's cultural environment and belonging to his or her learning ecology. It remains important to observe how persons experience themselves and the world in which they live, thus forming meanings and practises, and where they see opportunities and obstacles for quality of life. If people identify themselves with an activity or group, experiencing a sense of belonging, their behaviour is more likely to change. The community of practice model emphasises a sense of belonging and group identity that forms with common practice, non-hierarchical relationships, dialogue, and in situ learning.

We live in systems of consumption, neo-liberalism, and global capitalism (Krašovec, 2016a,b,c) and people often make "Eichman's" references to bigger systems, only obeying instructions. Therefore, it is essential to raise awareness and to encourage the development of critical thinking as part of sustainability transition. The work of Freire and his commitment to developing critical consciousness are (can be) used (Freire, 2013) by abandoning passive positions, through dialogue and activities that accept the good in traditional practices (heritage) and in developing new ones (ibid., p. 18). Deriving our approach from Freire's ideas, we are critical of modern concepts of people as mere "human capital" used in processes of production, and we are looking for new options to educate 
adults in so-called "non-traditional" spaces. In the Slovene environment, this is connected to the history of adult education in associations. We 're looking for possibilities to resist unlimited development, marked by environmental degradation, financial fraud, and human instrumentalisation. Grasroots innovations ${ }^{4}$, developed in the local environment, will not respond to the requirements of the market that transforms people and the entire planet into profit-making devices. They prefer to be based on principles of common good (cf. Del Gobbo and Bogataj, 2014; Bogataj, 2013). Our experiences with cooperation in local communities and associations demonstrate that local practices and the use of traditional knowledge may trigger innovative economic activities. One of the strategies for the development of social innovations is encouraging deliberative practices in adult groups that learn and work in the local environment. The concept of deliberative practice was used by Irena Sovdat to interpret education in the Sivka study circle (cf. Mohorčič, Sovdat and Ličen, 2017; Fakin Bajec, 2016a).

With all the changes (technological, managerial, material, financial, etc.), the development of sustainable behaviour requires community learning that leads to different practices; this cannot be accomplished by individuals. Education, according to the community of practice model, exposes learning as creating meanings and connections, or the learning of the second tier, which not only repeats patterns, but also develops new meanings and leads to active contributing (active citizenship). Learning means searching for new possibilities and being subversive to dominating practices, lead by the groups of social power and decision-making competency. The leading global system pursues unsustainable policies that causes degradation. Such policies will not encourage innovation that may disbalance the system. With their local impact, innovations in the local environment ${ }^{5}$, resisting the exploitation of the planet, influence the broader environment. This is compatible with the EAE definition. Clover (2003, p. 10) defines environmental adult education as engaged and participatory behaviour. Adult environmental education connects "the environment and social, economic, political, and cultural aspects of people"s lives". EAE is social learning and not a simple changing of individuals, therefore, the study of learning requires the appropriate theoretical model of social learning.

According to most authors on the subject (Plut, 2014; Mancini, 2015; Casey and Asamoah, 2016), consumer society causes environmental problems, thus the educational goal is also environmental justice, implicating raising awareness of the dynamics that generate inequalities, and encouraging active citizenship through activist projects. The educational process

4 Innovative grassroots models are becoming increasingly important (cf. Castells, 2013), while new practices emerge, cf. for example Honey Bee Network project in rural India, http://www.sristi.org/hbnew/, cf. innovative projects at the Slovenian Third Age University (for example Z menoj po mojem mestu, Personal Town Tours).

5 Let us mention two women eco-activists who faced many difficulties in their environments. Kenyan 2004 Nobel Prize winner Wangari Maathai (1940-2011) founded the Green Belt Movement and was imprisoned for her activism. With her work, Indian environmental activist Vandana Shiva (1952-) challenges prevailing consumption mental models. With their efforts, both surpass their local environment. 
thus develops a socially active paradigm and encourages various non-oppressive learning ecologies. Cases of such activities present the study subject in the second part of the article.

EAE refers not only to educating people on efficient use of energy, water, or green buildings, but also to comprehensive lifestyle changes. Therefore, it usually implies local, national, and global activism. The present research context is actually planetary (cf. Auge, 2014, p. VII) and ethnographic studies are not restricted to local frames, although selected cases are examined. Our research focuses on the local environment; nevertheless, we wish to emphasise that globalisation "trivialises" small local communities and consequently local communities themselves fail to notice particular innovation of practices that develop outside of major markets.

\section{THEORISING LEARNING AND ACTION NEXUS}

Though learning can be interpreted through various theories, some are more suitable for sustainable learning, as they include comprehension and activities as learning-action nexus. Among them, Freire's theory on the development of critical conscience has been mentioned. Freire (2013) argued that socially oppressed groups must develop critical conscience, i.e. the ability of critical assessment as to what causes social inequalities ${ }^{6}$, and the ability to act in a repressive environment. Having recognised possibilities for acting, people develop new competencies. Key factors thereof are reflection, dialogue and acting. Due to the important role of practice in understanding learning, our research derived from poststructuralist practice theory. This theory was the basis for the community of practice model, in which learning is understood as the process of an individual's changing in the world, acting with others according to symbolic structures. Learning is a part of man's participation in the world. The community of practice (CoP) model is typically not only a cognitive, but also an existential process; learning takes place through activities and social inclusion (by being engaged in a particular process), and people are included in the practice and in the social networks. Practices are understood as bodily and mental routines that involve activities, knowledge, objects and their uses, emotions, wishes, and motivation. Changes in routines come with learning. The CoP model presupposes a group of people who work together and learn to improve their activities. A CoP member learns through participation in social practices and knowledge and identity. Wenger $(2010 ; 2015)$ describes CoP as a group of people mutually interacting, sharing their field of action, their common explicit and implicit knowledge, and building common meaning, interpretations of events, and phenomena, as well as their identity.

Our hypothesis is that the realisation of sustainable development requires social innovation and the encouragement of a critical conscience, which is associated with individual and social learning. Furthermore, the article describes characteristics of the connection between learning and acting as an option for developing innovative practices. Connections are described through selected cases, researched with qualitative methods.

6 For more about causes and phenomena of social inequalities (cf. Brezigar, 2012). 
The purpose of our research was to determine the prospects of the innovative social practices in the context of the sustainable development paradigm through learning-action nexus. With a better knowledge of innovative social practices, transformative learning could be encouraged in other environments as well. New social practices could be merged and upgraded with various connecting and managing strategies. ${ }^{7}$

\section{EMPIRICAL SECTION}

Our empirical section will describe the cases of learning in communities that are socially active, non-oppressive, and that do not repeat the rules of consumer society, but that are rather developing new practices. We selected the following as our criteria:

(a) local connection and preservation of cultural heritage in an association;

(b) volunteering and preserving natural heritage in the older age study group;

(c) herbalism and the use of local herbs as part of natural heritage in nutrition and cosmetics, within a study circle.

All cases involve groups of people who learn and act, preserving cultural and natural heritage.

\section{METHOD}

Empirical research is conceived of as qualitative study, following the ethnography principles of observation through participant observation and analyses of artefacts and materials (Cardano, 2011; Campbell and Lassiter, 2015). We carried out data collection in three ways: with participant observation, documentation and product analysis (booklets, books, theatre performances, exhibitions, documentaries), and participant activity research, all three methods conducted contemporaneously with the development of new projects. In the latter, we used the living lab strategies. These strategies (cf. www.openlivinglabs.eu ${ }^{8}$ ) connect researchers and "users" who, as co-creators, have developed a new product or service to fulfil the needs of the local population.

Within the international Green Education Project (cf. Ličen et al., 2015), we collected data from 2013 to 2015. During the 2015-2016 academic year, we carried out participant observation within Sivka study circle (cf. Mohorčič, Sovdat and Ličen, 2017), and analysed booklets, books, documentaries, and exhibitions, as well as work reports, prepared by the Housewives' Association and its drama group from the village of Planina pri Ajdovščini. Our focus was on non-formal education for changes towards sustainable development taking place in local environments. The learning groups that set action and

7 There are studies on so-called Strategic Niche Management (SNM) that recognise and unite innovative practices, still part of development niches, however, with integration they can be developed as alternatives to existing, unsustainable practices. SNM is usually used to name societal incentives towards sustainable development and usually focuses on technological innovation, such as for example the use of wind energy or organic food production.

8 This type of research can be understood in the same vein as action research. 
education goals were considered communities of practice. All the of selected examples develop new practices in reference to their environments.

In this paper, we examine data from three specific environments:

(a) Sivka, a study circle in the village of Podraga,

(b) the Housewives' Association and its drama group in the village of Planina pri Ajdovščini,

(c) a garden volunteer programme at the Slovenian Third Age University.

Participant observation was the core of our research. It was complemented with informal interviews, according to the emancipatory interview principles. We observed how people learn while performing activities. It is important for observers to be extensively included in the observed activity so that trust can develop (Cardano, 2011). All three researchers were active in the researched environment. We followed the principle that each data collection technique must be context-sensitive (Czarniawska, 2004, p. 44), remaining aware of all of the advantages and deficiencies of our research being carried out locally (cf. Mughal, 2015).

The goal of our research was to contribute to the knowledge of innovative practices of mutual learning within common work; therefore, we explored how the following phenomena reflected in the community of practice:

(a) Connection between learning and acting (practices) and the types of relationships.

(b) Developing innovative practices.

(c) Transformation-focused learning.

\section{RESULTS AND DISCUSSION}

Results with discussions will be presented in thematic units, as formed in reference to the research goal.

\section{(A) CONNECTION BETWEEN LEARNING AND ACTING (PRACTICES) AND THE TYPES OF RELATIONSHIPS}

The most obvious of these is the learning-action nexus, in which one or the other cannot be excluded, which is known as theory and reflection in action. Learning-action nexus form out of an interconnected collective of people, instruments and discourses. All elements and all mutual relationships are important.

Learning is influenced by the basic activities in the community (social circles, association). Various methods and different types of knowledge appear in groups, and are further developed. All participants are volunteers, and women prevail in these groups. Garden volunteers concentrate on the characteristics of plants in the botanical garden, while the Housewives' Association and drama group from Planina pri Ajdovščini preserves and sustainably upgrades local traditional knowledge using various learning methods (theatre, books, exhibitions, events, courses, etc.). The Sivka study circle prepares herbal 
products and learns about herbs, organic production and the processing of vegetables and herbs. Organised education as goal-oriented process appears in all three groups; it is the most structured in the garden volunteers' group. It begins with training for activities in the botanical garden. Others' education is directly connected with activities, however, various short courses are organised between various events. The Housewives' Association and drama group organises cooking courses, with one housewife teaching others. They organise Italian language courses, taught and mentored by the member who is an Italian language teacher. The study circle organised a course about using computers as well. Locations for education differ, including non-traditional spaces (for example, learning in the garden, meeting in the parish house, in the old village school, in members' kitchens) and also traditional classrooms (e-learning in a people's university classroom, lectures in a third age university classroom, etc.). These rooms are part of the local environment, felt as something belonging to them, as part of their social identity. None of the groups have a determined curriculum; it forms in dialogue with the participants. At first sight, learning seems coincidental (collateral of the activity), with members simultaneously agreeing on which knowledge they need.

Learning and activism are connected. During the creation of these programmes, the ideas of using activities (volunteers in the botanical garden) to influence social perception of the elderly and the need to preserve plant species emerged. The Sivka study circle also engages in activism by organising Zelemenjava (Vegetable Exchange), and by raising awareness on the meaning of seeds in the association. Activism, as demonstrated in the examples we researched, is compatible with the principles of EAE, described by Clover et al. (2013). Activism is particularly emphasised within ecofeminism. Sivka initially had no explicit intention to be an agent of social change; it came as a spontaneous development during a manner of years. Initially, the study circle was intended to unite people with similar interests, and later it evolved into a platform for raising awareness in a broaderwi environment. The association's initial goals focused on group activities (preserving traditions, preparing dishes according to domestic recipes), later a wish to influence broader environment developed.

Relations between learning and acting which provoke changes (the development of new practices) are visible at three levels: the individual, the interpersonal, and the collective.

In all cases, social activities that required knowledge and are understood as informed actions were executed. When preparing Veg Exchange in the town market, theatre performances, and an exhibition, participants needed specific knowledge. Acting and learning merged at the individual level, at which each woman's activity was based on acquired knowledge such as planting their gardens, buying ingredients for dishes, herb harvesting, etc. Interpersonal learning and acting took place when a woman communicated to another person what she had learned. An example is tea preparation or cooking class, in which the person who has a specific knowledge conveys it to others in the group. Attention is also paid to the knowledge which is part of unverified (obsolete) beliefs. The study circe's mentor acts as authority in the field. In the association, the researcher had the role of the 
cultural heritage expert, or it could be filled by other invited professionals. In groups without an authority (a person renowned in the field, an expert), certain beliefs can spread because of the social power of a person influential in the group dynamics. Critical reflection, a questioning the validity of statements, is therefore always necessary. When study circle members share mutual experiences, it is wise to verify the experiential knowledge in comparison to scientific knowledge. Consequently, members often invite experts to their meetings or attend study tours. Members act as role models and hold workshops for children and other visitors in their local environment. Such examples are workshops in elementary schools and cooking classes for external visitors in the Youth House in Ajdovščina. Collective activity and learning means that the whole group worked in reference to other groups, connected to a broader social environment, and learning from contacts with other larger groups. Such an example is Zelemenjava (Vegetable Exchange) as the awareness-raising of a broader environment on the significance of exchange instead of sale. Similarly, there is also book preparation, in which association or study circle members meet with political actors in their local areas and convince them of the importance of environmental mindfulness.

All cases proved that activity and engagement are crucial for learning. Learning is part of an activity or intended to prepare an activity which coincides with theories on adult motivation for learning and education. Motivation for activities in study circles and associations is predominantly socially-oriented, as people want to socialise and create together. If necessary to realise an activity, they also undertake education. Adults wish to use their knowledge to improve life, thus learning is a collateral function of activities in a circle or association. Lange (2012) discovered that adults wish to be active in using their knowledge, and are particularly so when their knowledge is connected with ethical principles. In the observed examples, the majority of participants wanted to use their knowledge in their own environment. Knowledge and skills in the observed examples have always been connected with activities. Only some people treated education as a personal need, however, even these individuals acted using their knowledge. Some expressed their feelings that the knowledge was "real" only when they could put it to use. In their opinions, learning is not complete until it leaves a certain footprint in real life, in an activity which is environmentally just and means something good to other people.

N.S.S. (2015), a third age university student and volunteer at the Botanical Garden in Ljubljana said: "Taking care of plants, weeding, hulling seeds or autumn raking require knowledge. Its climax is guiding in the garden. To be able to do that is almost as demanding as graduating again. You are transformed, too."

Experiential knowledge application is the most powerful encouragement in generating further knowledge. Both connect to the transformation of knowledge and action. 


\section{(B) THE DEVELOPMENT OF INNOVATIVE PRACTICES}

Innovative practices in all three groups develop in tandem with various learning strategies. The learning process leads to different, holistically intertwined learning outcomes. First, the strategies used will be outlined and discussed.

Arts (writing, drawing, theatre), dialogical experiential learning (narrating and discussing experiences), short lectures, demonstrations (presenting how soap, dishes are prepared) were used as strategies to transfer knowledge and develop a sense of belonging. Narrative methods and project work with research were frequent. These strategies were not intentionally used to develop a sense of belonging to the group, but rather it formed in parallel with them. The basic goal was to organise an event, such as a theatre play or a collection of memories about picking herbs.

Intergenerational cooperation takes place (for example, young photographers took pictures for booklets/books, children participated in workshops prepared by associations and circles, the old and the young participated in an amateur theatre play).

In all cases in which they write about their work, they publish books and articles. Preparing texts on their work means to reconsider and compare it with others. The Housewives' Association and drama group's publications are more numerous than others', which can be the result of several years of cooperation by academically educated researchers. Several works on cultural heritage were published (Not to Forget. Customs and Recipes of our Ancestors (2005); Not to Forget II. Manners and Customs, and Recipes from Planina pri Ajdovščini (2014)). The Not to Forget II book gathers recipes of traditional dishes and new recipes that reflect knowledge and experiences, together with the courage and creative impetus of modern housewives. New recipes are authored by members of the association who used their knowledge to adapt old recipes for contemporary times and ingredients, previously unavailable or unknown. They collected stories about polenta (We Ate Polenta Every Night, Sometimes Even for Breakfast; On Corn Cultivation, Husking and Cooking Polenta at Planina in the Past and Future Challenges), Stories about School (2013). The Sivka study circle published a booklet with recollections about herb harvesting (2017).

Drama performances in dialect and short film production are the next learning strategy. To begin with, creating theatre performances and producing films have no educational purposes. At least for the authors! A theatre performance is created to raise awareness of the significance of environmental behaviours (promoting domestic seeds, organic farming), gender equality, and family problems, and to make people laugh. Examples of such performances are Ekola Domestic Fairs, Good Old School, That's Some Housewife, Family Dissentions, Tourism on Farm. Learning is present at the level of screenwriting, play preparation, memorising the text, staging, and performing. Moreover, "through the years, players developed their personalities, they became more self-confident, daring, convincing and joyful. Players admit it, since the oldest actress always likes to tell that playing in the group is "nerve pills" to her, as otherwise she would have lost courage when facing hardships in life. At rehearsals she relaxes, cheers up, laughs abundantly and thus finds 
it easier to conquer her old age problems." (Fakin Bajec, in Ličen, Findeisen and Fakin Bajec, 2015)

Workshops for members and local people were organised in study circles and associations. Groups prepared various workshops: making wreaths, decorating the place of an event, basket weaving, getting to know animals, etc. Workshops are often linked to projects containing exhibitions and other events (for example, an educational course for baking bread is prepared together with the exhibition on bread).

Innovative practices were not immediately accepted! It took time for the local society to recognise the value of these activities. In 2013, the Housewives' Association and drama group received a municipal award, and in 2015 a national award Our Slovenia for researching and re-establishing heritage. In 2016, the study circle mentor received a national awarded for her work in adult education. Initially they were confronted by doubtful members of the community. In the perspective of the role heritage plays in the modern globalised world, this is understandable, since some villagers who used to (or still) despise heritage activities succumbed to recently adopted public discourse on understanding the past as a symbol of poverty and backwardness. In Slovenia, this was most obvious during the socialist decades. The history of the farmers' lifestyle was presented in museums and at tourist events, however, primarily to demonstrate progress and as a method of strengthening common roots, needed to create a common consciousness. Interestingly, such behaviour of the villagers did not deter members from their activity, and actually it had quite the contrary effect. It strengthened the groups' activities. Gradually, the villagers' attitudes (according to participants, members) improved. More and more villagers began to use old seeds in their farms and they dedicated more time to re-awakening traditions. They recognise that the local past is not something backward, but on the contrary that it is an important source of a better future (cf. Fakin Bajec, 2016a).

When interpreting, objecting, doubting, and ridiculing, we are aware that communities are living systems, always containing oppositions as barriers to innovation development. Disagreements can be based on gender, social status, class. The community is not idealised or understood as a harmonious whole without objections. The task of the education is to develop the ability to accept changes. Understandably, some community members are more involved in group activities, others less; some are more aware of the local past, while due to different experiences, knowledge, needs, and possibilities, others are inactive, however, they have different knowledge and skills, rejected by others. Accepting diverse opinions in a community is important, as in this way personal rights are safeguarded and democratic behaviour preserved, argues Blake (2009).

A person with advanced knowledge or an engaged researcher may act as an important intermediary in developing internal cohesion and innovation. One of the authors of this article was an expert assistant in the association and played an important role in publishing books and also in encouraging innovation, manifested in their products, which merged tradition and innovation. Such examples are pasta from an old corn variety, "guštənca", 
and bread buns or "planinčki", with sugar figs. An external mentor and expert assistant, not burdened with local disagreements, enters into relationships with no preconceptions or negative experiences. The method of "academic scouting" may be useful for developing innovation, i.e. when researchers stay or cooperate in the environment in which new practices are being developed. Scientific knowledge is "poured" into common practices in the local environment, acting on the set beliefs and cultural routine. A CoP includes a researcher whom they trust in their network, and this contributes to a faster movement of knowledge.

Obstacles to the innovation development of innovation in the learning/acting nexus show at several levels: barriers exist at the personal level (character, emotional concerns, fear, burnout, knowledge-related barriers), interpersonal level (which emerge within group dynamics, poor relationships), and socio-cultural level (an environment with its social pressure, expected behaviour patterns). Initially, innovations were not accepted in the environment, and people mocked or openly opposed them. When introducing social innovation, we also need knowledge of how to innovatively encourage and implement it in a certain environment. Innovative practices take place in a local environment with the appearance of decentralised responsibility, as they do not follow municipal or national instructions, but rather have a grassroots framework. Developing an herbal garden, tea workshops, tourist events connected with apricot processing result from group's decisions and self-organisation.

\section{(C) LEARNING AND TRANSFORMATION}

The learning and educational process means a constant intermingling of learning (obtaining information, knowledge on plant species, dishes, plant names, protection, etc.) and skills (cultivation, planting, sowing, etc.), the development of cognitive maps or concept patterns, and acting and forming attitudes toward natural and cultural heritage. Participants adopted various types of knowledge. According to our hypothesis, innovative practices develop if actors build integrative knowledge that includes theoretical, practical, and reflective or metacognitive knowledge. Findings in this research have been classified in four types of knowledge, formed by Tynjälä (2013). The author operates from the theory of systems and activity theory, which is an appropriate division for the discussion on the theory of practice. The cases found in our examples will be added for each knowledge type (according to Tynjälä, ibid.).

- Conceptual knowledge (systematic knowledge leading to the understanding of a subject): information on cultivating herbs and other plants, knowledge of how to prepare milk products, knowledge of traditional festivals in the local environment, knowledge of cultural heritage, history of the place, etc.

- Practical (procedural) knowledge (it forms with experiences and involves simple or complex procedures): creating and using a FB site, basket weaving, preparing dishes, selling natural cosmetics, preparing a promotional event, etc.

- Self-regulative knowledge (the knowledge of self: the way of thinking and feeling, the knowledge that enables awareness of what and how a person knows something): 
knowing one's own emotional characteristics, facing stage fright, being ready to change attitudes, developing self-confidence, feeling enraptured, motivated and reflecting on all this after an event, etc.

- Socio-cultural knowledge (knowledge that enables one to live in a culture, understanding other cultures) means embracing team work, organising events in the local environment, relationships with others, the role of vegetable exchange instead of sales, attitude toward another culture (preparing Turkish borek), intergenerational and intercultural relationships.

The development of all four types of knowledge was encouraged by mentors in the groups. The transfer of contents built conceptual knowledge. The awareness of how cultural representations are built and organised through language and power structures (with particular attention to gender, since the participants were mostly women) created socio-cultural knowledge. The attitude toward women, their learning, political engagement, etc., evolved during their participation in circles, as did the attitude towards the ageing and learning of the elderly. In the ' environment' we researched, both women and the elderly have less social power in public life, while education was transforming their beliefs. Only with changed attitudes did they create potential for innovative breakthroughs. Liberated from fear or shame in their environment, they created events.

The integration of all types of knowledge leads to innovation. If procedural knowledge affects habits without sufficient conceptual knowledge (such as familiarity with new scientific findings), the repetition of certain processes may occur, obstructing insights into potential for innovation. If the self-regulative knowledge is impoverished, or if people are scared, they will not allow innovation, because they will not dare to exit into increased uncertainty. Each innovation brings uncertainty. In our examples, this included mastering abundant courage to leave old patterns and develop new ones (such as using home-grown seeds, natural cosmetics). Participants created new dishes. For the Apricot Day event, the Housewives' Association prepared an original dessert: "polenta made of guštənca" (a corn type) with apricot topping.

Encouraging the process of perfecting former knowledge, produce, and products, while adapting them to modern needs, knowledge, possibilities, and wishes means encouraging transformative learning. Such an example is the project of researching school life (the Housewives' Association and drama group). Participants in the old school project researched learning in the past, and attempted to use the findings to improve the quality of present life. The process of researching, awareness-raising and transforming is involved. In this project, special attention was paid to the school garden at Planina from the end of the 19th century. There, children learned farming skills, particularly marketing their products, as they sold the produced onion and garlic to the Farmers' cooperative in Ajdovščina, and invested the earnings to buy manure.

The contents, mentioned as the field of transformative learning, varied, nevertheless they always originated in participants' needs and activities. Preserving home-grown seeds lead 
to changing beliefs about seeds submitted to non-sustainable treatment. Preparing traditional and new dishes lead to reflections on modern ways of using preservatives, flavour enhancers, and colourings. The contents they met were connected to their experiences. Epistemology was not linear, and knowledge was transferred from researchers or experts (scientific knowledge) to users without neglecting their experiences and beliefs, feelings, values. New scientific findings merge with experiential knowledge and solutions, and users learn about traditional practices in the local environment (traditional place-based knowledge).

\section{CONCLUSION: GRASSROOTS INNOVATIONS AND TRANSFORMATIVE LEARNING}

If we want to implement sustainable development and pursue environmental justice, we need transformative and innovative learning. Consumer society reduces people to "human resources", which serve to optimise profit, instead of having profit to serve people. In the researched examples, "human resources" seem to resisted consumer society rules and proceed in a different way. Our research on innovative learning in local environments indicates possibilities to develop new practices, based on mutual connections. As community gardens gain popularity in urban environments, various groups in our research (study circles, associations, volunteers) are gaining importance in the development of innovative practices in rural environments. Links between learning and acting and links between scientific and traditional knowledge are compatible with development, based on cultural and natural heritage and on the principle of well-being in harmony with nature. These examples demonstrate that CoP methodology lends itself to the development of innovation, taking account of all types of knowledge, the local identity, and environmental needs. Promoting grassroots innovation further encourages local development and emancipates people towards ecojustice.

Findings by Grasseni (2007), Wenger et al. (2015), Moyer, Sinclair and Quinn (2016), Fakin Bajec (2016a; 2016b) indicate that groups which intertwine activities and dialogical and transformative learning are important factors in the development of innovative practices. Our research contributes to the critical assessment concerning the creation of knowledge and routines, which can be an obstacle, and a source for searching new practices. When people break with the customary way of thinking and, through critical reflection, shift to transformative learning, they begin forming innovative practices. Sustainable society must abandon existing behaviour patterns and inventing new ones. In the future, people will change in ways yet unknown to us, while learning means constant openness to novelties. For further research, we would need findings on what hinders people from inclusion in groups that contribute to local development.

The key finding is that transformation did not take place without resistance, but that it needed a group of people who persevered in spite of slight mocking in their surroundings (members' emotional competencies); scientific behaviour which intertwined with local 
traditional behaviour was important. The groups included in our research were not involved in a re-active participation - on the contrary, they created new practices and their social identity themselves.

\section{REFERENCES}

Augé, M. (2014). L’antropologo e il mondo globale. Milano: Raffaello Cortina Editore.

Barbič, A. (2005). Izzivi in priložnosti podeželja. Ljubljana: Fakulteta za družbene vede.

Blake, J. (2009). UNESCO's 2003: Convention on Intangible Cultural Heritage: The Implication of Community Involvement in »Safeguarding «. In L. Smith and N. Akagawa (Ed.), Intangible heritage (pp. 45-73). London: Routledge.

Bogataj, N. (Ed.). (2013). Znamenja trajnosti. Ljubljana: Andragoški center Slovenije.

Brezigar, S. (2012). Do Third Country Nationals in Slovenia Face Prejudice and Discrimination?. Dve domovini, 35, 149-161.

Campbell, E. and Lassiter, L.E. (2014). Doing Ethnography Today. New York: Blackwell.

Cardano, M. (2011). La ricerca qualitativa. Bologna: Il Mulino.

Casey, C. and Asamoah, L. (2016). Education and Sustainability: Reinvigorating Adult Education's Role in Transformation, Justice and Development. International Journal of Lifelong Education, 35(6), 590-606.

Castells, M. (2013). Networks of Outrage and Hope: Social Movements in the Internet Age. New York: Wiley \& Sons.

Chen, J. and Martin, A. (2015). Role-Play Simulations as a Transformative Methodology in Environmental Education. Journal of Transformative Education, 13(1), 85-102.

Clover, D.E. (2003). Environmental Adult Education: Critique and Creativity in a Globalizing World. In D.E. Clover and L.H. Hill (Eds.), Environmental Adult education: Ecological Learning, Theory, and Practice for Socioenvironmental Change (pp. 5-15). San Francisco, CA: Jossey-Bass.

Clover, D.E., Jayme, B., Hall, B.L., and Follen, S. (2013). The Nature of Transformation. Environmental Adult Education. Rotterdam: Sense Publishers.

Cranton, P. and Taylor, E.W. (2012). Transformative learning theory: Seeking a more unified theory. In E. Taylor, and P. Cranton (Eds.), The Handbook of Transformative Learning: Theory, Research, and Practice (pp. 3-20). San Francisco: Jossey Bass.

Czarniawska, B. (2004). Narratives in Social Science Research. London: Sage.

Del Gobbo, G. and Bogataj, N. (2014). Izobraževanje odraslih za razvoj lokalne skupnosti: izkušnje čezmejnih študijskih krožkov. Andragoška spoznanja, 20(1), 7-19.

Fakin Bajec, J. (2014). Razvojni potenciali kulturne dediščine za blaženje sodobnih družbenih in gospodarskih problemov. Glasnik Slovenskega etnološkega društva, 54(4), 18-26.

Fakin Bajec, J. (2016a). Cultural Heritage and the Role of Voluntary Associations in the Process of Achieving Sustainable Development in Rural Communities. Studia ethnologica croatica, 28(2), 21-45.

Fakin Bajec, J. (2016b). Vloga etnologa in kulturnega antropologa pri razvoju družbe znanja na primeru Društva gospodinj in dramske skupine s Planine pri Ajdovščini. Goriški letnik, 39/40, 261-273.

Freire, P. (2013). Education for Critical Consciousness. London: Bloomsburry Publishing.

Grasseni, C. (2007). Communities of Practice and Forms of Life: Towards a Rehabilitation of Vision? In M. Harris (Ed.), Ways of Knowing (pp. 203-221). New York and Oxford: Berghahn Books.

Harrison, R. (2008). Heritage, Memory and Modernity: An Introduction. In G. Fairclough et al. (Ed.), The Heritage Reader (pp. 1-12). London and New York: Routledge. 
Krašovec, P. (2016a). Še enkrat o neoliberalizmu. I, Ekonomija. Andragoška spoznanja, 22, (1), 57-70. Krašovec, P. (2016b). Še enkrat o neoliberalizmu. II, Politika. Andragoška spoznanja, 22(1), 71-84.

Krašovec, P. (2016c). Še enkrat o neoliberalizmu. III, Psihoafektivni učinki neoliberalizma in neoliberalna subjektivnost. Andragoška spoznanja, 22(2), 67-79.

Lange, E. (2012). Transforming Transformative Learning through Sustainability and the New Science. In E. Taylor and P. Cranton (Eds.), The Handbook of Transformative Learning: Theory, Research, and Practice (pp. 195-211). San Francisco: Jossey Bass.

Ličen, N., Findeisen, D., Fakin Bajec, J. ... et al. (2015). Zeleno izobraževanje: izbrane andragoške prakse. Ajdovščina: Ljudska univerza.

Lükő, I. and Kollarics, T. (2013). The Significance of Environmental Sustainability in Adult Environmental Education. International Journal of Environmental Protection, 3(1), 1-9.

Mancini, R. (2015). Ripensare la sostenibilita. Milano: F. Angeli.

Manners, E., Wake, D. and Carlise, R. (2009). Smogbusters: Grassroots Action for Clean Air and Sustainable Transport in Australia. Applied Environmental Education \& Communication, 8(1), 18-29.

Mohorčič, N., Sovdat, P. and Ličen, N. (2017). Sivka. Ajdovščina: Ljudska univerza Ajdovščina.

Monroe, M.C., Andrews, E. and Biedenweg, K. (2007). A Framework for Environmental Education Strategies. Applied Environmental Education and Communication, 6(1), 205-216.

Moyer, J.M., Sinclair, A.M. and Quinn, L. (2016). Transitioning to a More Sustainable Society: Unpacking the Role of the Learning-Action Nexus. International Journal of Lifelong Education, 35(3), 313-329.

Mughal, M.A.Z. (2015). Being and Becoming Native: A Methodological Enquiry into Doing Anthropology at Home. Anthropological Notebooks, 21(1), 121-132.

Orlović Lovren, V. (2012). Koncept održivog razvoja i doživotnog učenja - dva okvira za jedan pogled na obrazovanje odraslih. Andragoške studije, 19(1), 9-22.

O‘Sullivan, E. and Taylor, M. (Eds.) (2004). Learning Toward an Ecological Consciousness: Selected Transformative Practices. New York: Palgrave.

Plan B za Slovenijo 2.0 (2010). Retrieved from http://www.umanotera.org/wp-content/uploads/2014/10/ zbornik-plan-b-2.0.pdf.

Plut, D. (2006). Mesta in sonaravni razvoj: geografske razsežnosti in dileme urbanega sonaravnega razvoja. Ljubljana: Znanstvenoraziskovalni inštitut Filozofske fakultete.

Plut, D. (2014). Ekosoci[a]lizem ali barbarstvo: demokratični ekološki socializem in trajnostni sonaravni razvoj. Ljubljana: Društvo Gibanje za trajnostni razvoj Slovenije.

Shiva, V. (2005). Globalization's New Wars: Seed, Water and Life Forms. New Delhi: Women Unlimited. Shiva, V. (2014). Making Peace with the Earth. New Delhi and New York: Women Unlimited, Palgrave. Tynjälä, P. (2013). Toward a 3-P Model of Workplace Learning: A Literature Review. Vocations and Learning, 6(1), 11-36.

UN United Nations (2015). Transforming Our World: The 2030 Agenda for Sustainable Development. New York: United Nations.

Unesco (2015). Rethinking Education: Toward a Global Common Good? Paris: Unesco.

Vidmar, T. (2014). New Dimensions of Understanding of Lifelong Learning from Antiquity to Comenius. Review of European Studies, 6(3), 91-101.

Wenger, E. (2010). A Social Theory of Learning. In K. Illeris (Ed.), Contemporary Theories of Learning (pp. 209-219). London and New York: Routledge.

Wenger-Trayner, E., Fenton-O`Creevy, M., Hutchinson, S., Kubiack, C. and Wenger-Trayner, B. (2015). Learning in Landscape of Practice: Boundaries, Identity, and Knowledgeability in Practice-Based Learning. New York: Routledge. 